\title{
ŽENA I SPORT
}

\section{Nenad Ponorac ${ }^{1}$, Stanislav Palija ${ }^{2}$ i Mira Popović ${ }^{3}$}

${ }^{1}$ Medicinski fakultet, Univerzitet Banja Luka, Bosna i Hercegovina

'Zavod za fizikalnu medicinu i rehabilitaciju "Dr Miroslav Zotović", Banja Luka, Bosna i Hercegovina

${ }^{3}$ Zavod za medicinu rada i sporta Republike Srpske, Banja Luka, Bosna i Hercegovina

\section{SAŽETAK}

Redovna fizička aktivnost važna je za zdravlje oba pola. Međutim, fiziološke, anatomske, psihološke i socijalno-kulturološke specifičnosti ženskog pola zahtijevaju posebne obzire u svim sferama njihovog bavljenja sportom. Pubertet donosi razlike među polovima koje su posljedica različitog funkcionisanja polne endokrine osovine. Uprkos identičnim mehanizmima adaptacije na fizičku aktivnost polno zrele žene i muškarci imaju nasljeđene anatomske i fiziološke različitosti u tjelesnoj kompoziciji, aerobnom kapacitietu i mišićnoj snazi. Naročito se odnosi na mnogo složeniji ženski reproduktivni sistem. Ženski reproduktivni sistem predstavlja funkcionalni dio ljudskog tijela najosjetljiviji na stres izazvan teškim fizičkim naporom. Najčešći poremećaji čiji rizik se znatno povećava kod fizički aktivnih žena su poremećaj ishrane, narušen menstrualni ciklus, infertilitet, stres frakture, rupture prednjeg ukrštenog ligamenta ili čak smrt. Uglavnom su posljedica grubih grešaka i neznanja. Srećom, dobrom prevencijom uglavnom ih je moguće spriječiti.

Ključne riječi: fizički napor, ishrana, menstrualni ciklus, stres fraktire, ženska sportska trijada.

\section{UVOD}

Istorijski medicinski dokument US Surgeon General's Report On Physical Activity And Health je dao čvrste naučne dokaze da je redovna fizička aktivnost veoma važna za zdravlje, kako muškaraca tako i žena, sa preporukom aktivnog učešća u svim vidovima fizičke aktivnosti i sporta (U.S. Department of Health and Human Services, 1996). Međutim, fiziološke, anatomske, psihološke i socijalno-kulturološke specifičnosti ženskog pola zahtijevaju posebne obzire u svim sferama njihovog bavljenja sportom (Greydanaus i Patel, 2002). Ženama su danas dostupn asva sportska borilišta, ali nije oduvijek bilo tako. Prve Olimpijske igre (776. god. pne.) bile su privilegija i zadovoljstvo dato samo muškarcima. Žene su satisfakciju potražile na Igrama u čast boginje Here, zaštitnice žena toga doba. I prve moderne Olimpijske igre, održane 1896. godine, imale su sličan trend za žene, znači, bez mogućnosti da one na njima učestvuju (Ponorac, 2008).
Početak 20. vijeka donosi progres u tom pogledu, a žene se polako uključuju u sve veći broj sportskih aktivnosti. Tako, polako ali sigurno, postaju dio sportskog života. Na drugim Olompijskim igrama učestvovalo je 12 žena, takmičeći se u tenisu i golfu, takozvnim sportovim više klase (Pfister, 2000). Porast učešća žena u sportu buknuo je u drugoj polovini 20-tog vijeka, a 23. jula 1972. godine osvanuo je još jedan 8. mart, ovog puta u sportu. Američki predsjednik Nikson potpisao je čuveni Title IX (Education Amendment Act) koji kaže da "niti jedna osoba u SAD-u ne može, na bazi pola, biti isključena iz učešća, uskraćena od olakšica ili biti predmet diskriminacije za bilo koji edukativni program ili aktivnost finansiranu iz državnih sredstava" (Mitchell i Ennis, 2007).

Od trenutka potpisivanja Titla IX do 80-tih godina prošlog vijeka broj stipendiranih pa tako i žena aktivno uključenih u sport porastao je $700 \%$, a tokom 90 -tih za još $50 \%$. Početkom novog milenijuma, 1 od 3 srednjoškolke u SAD-u aktivno je učestvovala u sportu za razliku od 1 od 27 u 1972. godini (Ireland 
i Ott, 2004). U Londonu 2012. postignut je još jedan rekord, rekordan broj učesnica, njih $46 \%$ od preko 10,000 učesnika, dok je 1908 godine taj odnos bio 53:1 u korist muškaraca.

Bavljenje sportom daje ženama mnoge prednosti. Potvrđeno je, da djevojčice aktivne u sportu imaju bolji uspijeh u školi, rjeđe se suočavaju sa neželjenom trudnoćom u tinejdžerskom dobu, posjeduju veće samopoštovanje i samopouzdanje, lakše se i češće upisuju na koledže i fakultete i mnogo rjeđe imaju problema sa zloupotrebama opojnih droga i bolestima zavisnosti. Vježbe sa težinskim opterećenjem imaju neprocjenjivu korist za razvoj i održavanje koštane mase kod žena u svim životnim dobima (Hagen, 2005).

Međutim, priroda nije potpisala deklaraciju o ravnopravnost polova u sportu. Što se fizičke aktivnosti tiče narod je još davno rekao da su žene „slabiji pol“. Paralelno sa trendom da se svi sportovi mogu upražnjavati, zarad ravnopravnosti polova, kod žena dolazi do razvoja mnogih karakteristika koje su evolucijski karakterisale muški pol. Po riječima Nikole Grujića, biologija je kroz evoluciju već napravila razlike u polovima u odnosu, pre svega na svoje reproduktivne uloge, pa „mešanje u njene poslove“ za odgovor ima posledice koje su nesagledive i čija je cena u pojedinačnom slučaju izuzetno skupa. Ta cijena može biti plaćena kao poremećaj ishrane, narušen menstrualni ciklus, infertilitet, stras frakture, rupture prednjeg ukrštenog ligamenta ili čak smrt. Da li se isplati? O njima ćemo diskutovati u narednim odjeljcima.

\section{FIZIOLOŠKE I ANATOMSKE SPECIFICNOSTI SPORTISTKINJA}

Pošto je danas većina sportova podjednako dostupna za oba pola, tako su i sportski rezultati često iznenađujući. Razlike u vrijednostima svjetskih rekorda u muškim i ženskim disciplinama nisu više tako drastične i kreću se unutar raspona do 15\%. Pred nauku, posebno fiziologiju sporta, postavljaju se nova pitanja, da li je to rezultat stvarnih bioloških razlika među polovima i gdje se prelazi tanka granica između fioziologije i patologije?

Prepubertalni dječaci i djevojčice imaju uporedive fizičke sposobnosti, uopšteno, mogu da igraju u istim timovima i da se takmiče jedni protiv drugih do 10-te godine starosti (Ireland i Ott, 2004).

Pubertet uzrokuje značajne razlike među polovima koje su posljedica različitog funkcionisanja polne endokrine osovine, odnosno prisustva testosterona sa jedne te estrogena i progesterona sa druge strane. Naročito se to odnosi na mnogo složeniji ženski reproduktivni sistem.
Uprkos identičnim mehanizmima adaptacije na fizičku aktivnost polno zrele žene i muškarci imaju nasljeđene anatomske i fiziološke različitosti koje se ogledaju u tjelesnoj kompoziciji, aerobnom kapacitietu i mišićnoj snazi.

Tjelesnu kompozicaju žena karakteriše manja ukupna masa, manji procenat mišićnog tkiva, a veći masnog.

Manja mišićna masa odnosi se uglavnom na manji promjer pojedinačnog mišićnog vlakna To je logično uzevši u obzir anabolički efekat testosterona i blagu predominaciju mišićnih vlakna Tip I koja su sama po sebi manjeg promjera. Tako žene imaju manju sposobnost da generišu apsolutnu silu, posebno u gornjim ekstremitetima koja je čak za 50\% manja u odnosu na muškarce. Ali kada se snaga izrazi po relativnoj mišićnoj masi, masi tijela ili poprečnom presjeku mišića razlike se znatno smanjuju. Žene imaju i prosječno za 5-15\% manji aerobni kapacitet. Ove razlike ne potiču od razlika u mišićnim vlaknima (kapilarizacija, sadržaj mitohondrija i enzima aerobnog metabolizma) nego u sposobnosti da se kiseonik dopremi do njih. Žene imaju manji udarni volumen pa tako i minutni volumen. Manji volumen krvi, hematokrit i hemoglobin dopirnose manjem aerobnom kapacitetu. I ova razlika se pripisuje testosteronu koji pored anaboličkog ima ulogu i stimulacije hormona eritropoetina (Kenney, Wilmore i Costil, 2012).

Veći procenat tjelesne masti žene duguju hormonu estrogenu. On stimuliše odlaganje masti u potkožno tkivo, tkivo dojke i posebno u glutealni predio i butine. Visoka aktivnost lipoproteinske lipaze tokom puberteta uzrokuje deponovanje masti u ovim područjima i njeno teško gubljenje. Zajedno sa širenjem karlice ovo daje posebno obilježje ženske figure. Često je ovakva izgled izvor nezadovoljstva žene pri čemu se grubo zanemaruje njegova stvarna uloga. Tokom zadnjeg trimestra trudnoće i cijele laktacije aktivnost lipoproteinske lipaze se samnjuje i započinje razgradnju, što navodi na zaključak da je mast ovdje uskladištena isključivo kao energetska podrška trudnoći, dojenju pa tako i produžetku vrste (Bjorntorp, 1986).

Najupečatliivija anatomska razlika se odnosi na dimenzije karlice, koja je većom širinom podređene procesu rađanja. Posljedično je izmjenjena anatomskoj poziciji i načinu kretanja donjih ekstremiteta (Ireland i Ott, 2004). Takozvani Sindrom Lošeg Poravnanja (miserable malaligment syndrom) predstavlja skup anatomskih varijacija donjih ekstremiteta žene koji vjerovatno daju predispoziciju za nestabilnost, bol u koljenu i konačno učestalije povređivanje prednjeg ukrštenog ligamenta (Myer i Ford, 2004). Njega u ekstremnim slučajevima čine femoralna anteverzija, na koju se nadovezuje ugao kvadricepsa (q-ugao) veći 
od 15 stepeni, vanjska tibijalna torzija, povećana pronacija stopala, zaravnjeno stopalo (pes planus) i hipoplastičan musculus vastus medijalis obliqus (Slika 1). Ovaj sindrom, uz razlike u neuromuskularnom refleksnom odgovoru, hormonskom statusu (uticaju estrogenih receptora na ligamente), i naravno razlikama u treningu uzrokuje i do 7 puta veću učestalost poverda prednjeg ukrštenog ligamenta i veću učestalost patelofemoralnog sindroma kod sportistkinja u odnosu na sportiste (Ireland i Ott, 2004).

\section{MEDICINSKI ASPEKTI BAVLJENJA SPORTOM KOD ZENA}

\section{Ženska sportska trijada}

Povećanje broja žena koje učestvuju u sportu povećao je i opasnost od rizika za sve negativne posljedice koje prate bavljenje sportom. Opasnost je naglašena pošto žene počinju bez ikakvih ograničenja

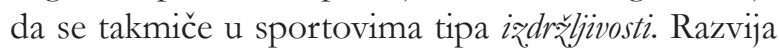

\section{SLIKA 1}

Maligament sindrom.

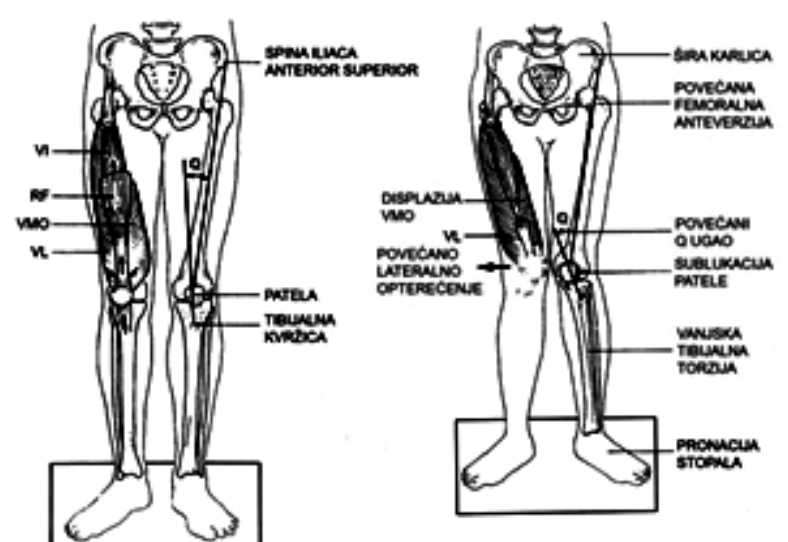

se i veći broj sportskih disciplina tipično ženske profilisanosti sa jakim naglašavanjem spoljašnjeg izgleda žene.

Ženski reproduktivni sistem predstavlja funkcionalni dio ljudskog tijela najosjetljiviji na stres izazvan teškim fizičkim naporom i sportom (Yeager, Agostini, Nattiv i Drinkwater, 1993).

Ranih 90-tih prošlog vijeka je postala vidljiva povezanost između poreméaja ishrane sportistkinja, poremé́aja menstrualnog ciklusa i poremé́aja matabolizma (mineralizacije) kosti. Njih je Yeager i sardnici (1993) ukloplio u sindrom poznatiji kao Ženska Sportska Trijada (Female Atblete Triad). Otkako je gimnastičarka Christy Henrich umrla 1994. godine u 22-oj godini i sa $29 \mathrm{~kg}$ težine, zbog bizarne primjedbe trenera da je „predebela“ za olimpijski tim, u medicinskim krugovima upaljeno je crveno svjetlo upozoronja za svaki od pojedinačnih simptoma Trijade. Potencijalni uticaj svakog pojedinačnog poremećaja ili kombinacija više njih dokazali su se štetnim kako za zdravlje tako i za uspjeh u sportu (Drinkwater, Loucks, Sherman, Sundgot-Borgen i Thompson, 2005).

Tri ugla Trijade su međusobno višestruko isprepletani fiziološkim i psihološkim mehanizmima, a prisustvo jednog od simptoma zahtijeva neodložno ispitivanje osobe i na prisustvo ostalih (Barrack, Ackerman i Gibbs, 2013).

\section{Poremećaji ishrane}

Poremećaji ishrane predstavljaju kontinuirani model poremećaja. Kreće se od abnornalnih navika pri ishrani sa ciljem redukcije tjelesne težine, pa do ozbiljnih kliničkih stanja koja završe i smrću (Goldstein, Dechant i Beresin, 2011).

U kontinuumu se nalaze klinički poremećaji, $A n$ orexia Nervosa, Bulimia Nervosa i posebna kategorija Nespecifikovani Poremécaji Ishrane (Eating disorders not otherwise specified - EDNOS) ("Diagnostic and statistical manual of mental disorders", 1994).

- Anorexia Nervosa predstavlja najteži poremećaj ishrane koji često završava letalno. Oboljela osoba sebe doživljava "predebelom" i pati od straha prema povećanju tjelesne težine, iako često ima i 15\% manje od očekivane tjelesne mase.

- Bulimija Nervosa se karakteriše cilkusima restrikcije u ishrani ili gladovanju koje prate faze nekontrolisanog prejedanja radi tzv. psihološke gladi, nakon čega slijedi faza čišćenja. Čišćenje podrazumijeva indukovano povraćanje, upotrebu laksativa ili diuretika (purging tip) i gladovanje i ekstremno vježbanje (non-purging tip), sa ciljem vraćanja na staro stanje. Sportistkinje 
sa bulimijom najčešće su normalne težine (Sundgot-Borgen i Larsen,1993).

- Nespecifikovaniporemé́aji ishrane (EDNOS) odnose se na široki spektar poremećaja ishrane koji ne zadovoljavaju sve kriterije kliničkih poremećaja. Osobe su normalne težine, međutim, prisutna je preokupacija ishranom, tjelesnom težinom, oblikom i tjelesnom kompozicijom.

- Subkliničke forme poremećaja ishrane postoje u mnogim slučajevima poremećene ishrane gdje sportistkinja pokušava da smanji tjelesnu težinu ili procenat tjelasne masti izlažući se restrikcijama ishrane (dijeta), izbjegavanju određene vrste namirnica ili praktikujući druge nenormalne navike u ishrani bez postizanja kriterija za poremećaje ishrane (Sabatini, 2001).

- Energetski deficit (Low Energy Availability) predstavlja stanje u sportu koje je uzrokovano smanjenim energetskim unosom ishranom ili znatno povećanom energetskom potrošnjom putem fizičke aktivnosti. Energetski deficit bez poremećaja $\mathrm{u}$ ishrani često je udružen sa poremećajima menstrualnog ciklusa i predstavlja ,polaznu tačku“ za razvoj Trijade.

Tačan procenat sportistkinja sa poremećenom ishranom je teško utvrditi jer je to simptom Trijade koji se najčešće prešućuje i previđa. Studije pokazuju veću učestalost poremećaja u ishrani kod sportista u odnosu na nesportiste, sportistkinja u odnosu na sportiste (Coelho i saradnici, 2013). Pod velikim rizikom su sportistkinje koje učestvuju u sportovima sa naglašenim estetskim izgledom (ples, gimnastika, balet), sportovima tipa izdržljivosti (atletika, plivanje, biciklizam) kao i one koje se takmiče po težinskim kategorijama (borilački sportovi). Učestalost anoreksije i bulimije po DSM-IV kriterijima u normalnoj populaciji iznosi od 1\% do 3\% dok procenat poremećaja ishrane u populaciji sportistkinja iznosi od 15\% do $62 \%$, zavisno od vrste sporta (Sundgot-Borgen Torstveit, 2004).

Kao moguće uzroke poremećaja ishrane litaretura navodi:

- Dijete - Restriktivna ishrana sa ciljem smanjenja tjelesne mase je primarni uzrok u razvoju poremećaja ishrane.

- Kalorijski deficit. Nagli porast u obimu treninga može uzrokovati kalorijski deficit.

- Početak sport-specifičnog treninga prije puberteta. Sportistkinje kod kojih su utvrđeni poremećaji ishrane započinjale su karijeru ranije u odnosu na ostale sportistkinje (Thomson i Sherman, 1999). Ukoliko sport-specifični trening započne prije puberteta, nagli rast i razvoj mogu dovesti do nesklada između oblika tijela i zahtijeva izabranog sporta, što kao posljedicu može imati pokušaj promjene tjelesne kompozicije snažnom restrikcijom ishrane (Deimel i Dunlap, 2012).

- Traumatska iskustva. Najčešća traumatska iskustva koja utiču na razvoj poremećaja ishrane su promjena ili gubitak trenera te bolest ili povreda sportiste, što se manifestuje poteškoćama u treningu. Ovo često dovodi do povećanja tjelesne mase ili u nekim slučajevima do straha od toga, što vodi ka posljedičnom kompenzatornom redukovanju unosa hrane. Moguće traume su i slučajne upadice i komentari u odnosu na tjelesni izgled, loše uspjeh u školi, problemi sa partnerom ili roditeljima, smrt prijatelja i konačno, a nerijetko, seksualno zlostavljanje od strane trenera (Drinkwater i saradnici, 2005).

- Ubijedenja da smanjenje tjelesne mase ili procenta masti dovodi do poboljšanja fizičke sposobnosti. Početni gubitak mase često može poboljšati fizičku spremnost. Taj početni uspjeh može uticati na sportistkinju da nastavi sa gubljnjem mase do granica razvoja poremećaja ishrane. Sportisti to često komentarišu "jednostavno se desilo, nikad nije ni planirano".

Treneri često daju svoj prilog ovom faktoru rizika, stimulišući na taj štetan i neprirodan način poboljšanja fizičke sposobnosti svojih sportista.

Zvaničan je stav IOC-a, da treneri ne mogu da procjenjuju tjelesnu kompoziciju sportistkinje, cake ni da daju sugestije. Preporućeno je da mogu samo da izraze svoju zabrinutost ili stav oko toga i upute sportistu ljekaru ili specijalisti dijetetičaru-nutricionisti. On ce nakon pažljive procjene $i$ pregleda, zajedno sa sportistom odluciti o mjerama za korekciju tjelesne mase (Ibid).

Posljedice na zdravlje koje ostavljaju poremećaji ishrane zahvataju mnoge sisteme, a smrtnost od anorexie nervose, kao najteža iznosi $6 \%$.

Rane posljedice su smanjenje bazalnog metabolizma, crpljenje rezervi glikogene u mišićima i jetri, smanjenje mišićne mase i dehidracija. Ovo sportistu čini osjetljivijim na zamor i mišićno-koštane povrede zbog narušene izdržljivosti, snage, koordinacije pokreta i koncentracije. Elektrolitni disbalans može dovesti do ozbiljnih poremećaja ritma srca, a pogođeni su i endokrini sistem i termoregulacija. Bulimičari pate od ozbiljnih gastro-intestinalnih problema a uvećanje parotidnih žlijezda i erozia zubne gleđi su posljedica učestalog povraćanja (Otis, Drinkawater, Johnson, Loucks i Wikmore, 1997).

Kasne posljedice predstavljaju deficit estrogena i posljediči poremećaji menstrualnog cikluca, sto predstavlja vezu izmedu prva dva simptoma Trijade. 


\section{Poremećaji menstrualnog ciklusa}

Mjesečni menstrualni ciklus predstavlja složenu interakciju između endokrinog i reproduktivnog sistema žene. Normalan, regularan menstrualni ciklus (eumenoreja) traje od 24-36 dana, prosječno 28 dana. Najčešće se počinje menarbom - prvim menstrualnim krvarenjem u dobi od prosječno 12,88 godina u Sjevernoj Americi i 13 godina u Evropi (Ibid).

Širok spektar poremećaja menstrualnog ciklusa može se pronaći kod fizički aktivnih žena, naročito sportistkinja.

- Oligomenoreja kao termin odnosi se na nepravilne menstrualne cikluse sa intervalom pojave krvarenja dužim od 36 dana ili 3 do 6 perioda u godini.

- Primarna amenoreja definiše se kao nepojavljivanje menstrualnog ciklusa do dobi od 16 godina kod djevojaka sa prisustvom sekundarnih polnih odlika ili nepojavljivanje menstrualnog krvarenja do 14 godine uz nerazvijenost sekundarnih polnih odlika .

- Sekundarna amenoreja definisana je kao izostanak tri ili više uzastopnih menstrualnih ciklusa nakon menarhe a u odsustvu trudnoće, ili manje od tri perioda godišnje (Nativ i saradnici, 2007).

Učestalost menstrualnih disfunkcija u normalnoj, odrasloj populaciji iznosi $2 \%-5 \%$ dok u sportu široko variraju u zavisnosti od vrste sporta, ranga takmičenja i mnogih drugih parametara i kreću se od $20 \%$ i do nevjerovatnih $70 \%$ u pojedinim uzorcima (Elford i Spence, 2002). Generalno, najveća učestalost je zabilježena u sportovima tipa izdržljivosti, sportovima sa težinskim kategorijama i sportovima sa naglašenim estetskim izgledom. Do sličnih podataka došao je i Ponorac ispitujući uzorak elitnih nacionalnih sportiskinja. Učestalost svih menstrualnih disfunkcija bila je veća u grupama sportistkinja u odnosu na kontrolnu grupu. Primarna amenoreja nađena je kod $8,33 \%$, a oligomenoreja kod $13,09 \%$ sportistkinja (Ponorac, Rašeta, Radovanović, Matavulj i PopadićGaćeša, 2011).

Jedan od najprihvatljivijih mehanizama nastanka menstrualnih poremećaja u sportu obuhvata i poremećaje ishrane. Energetska dostupnost/raspoloživost je definisana kao energetski kalorijski unos umanjen za energiju potrošenu tokom fizičke aktivnosti. Neravnoteža između energetske potrošnje tokom fizičke aktivnosti i kalorijskog unosa uzrokuje da tijelo prima informacije o neadekvatnim energetskim skladištima neophodnim za podršku reprodukciji i razvoju fetusa. Organizam tada ulazi u stanje "konzervacije energije" a reproduktivni sistem, kao luksuzna funk- cija, se u cilju samozaštite veoma efikasno gasi, odnosno po neformalnoj terminologiji ulazi u "shut down" stanje. Ova vrsta amaenoreje je nazvana funkcionalna hipotalamičk a amenoreja (HPA), a često kao sinonim ima i termin Sportsku Amenoreju (Catherine i Gordon, 2010).

Amenoreja nije niti željeno niti "normalno" stanje uzrokovano sportom. Ovulaciju kod amenoreičnih sportistkinja je teško predvidjeti, pa su moguće neželjene trudnoće što je posebno komplikovano u sezoni važnih takmičenja. Povećan je rizik od endometrijalne hiperplazije $i$ adenokarcinoma uterusa.

Međutim, najtežu posljedicu, a i treći simptom Trijade rini gubitak koštane mase i posljedična osteoporoza (TheinNissenbaum, 2013)

\section{Poremećaj metabolizma kosti (Osteoporoza)}

Kost je metabolički aktivno tkivo, a remodelovanje kosti koje podrazumijeva resorpciju i formiranje kosti, proces koji se odvija cijelog života. Ravnoteža između ova dva procesa omogućava održavanje ukupne koštane mase i morfološke građe kosti. Najmanje $60-70 \%$ maksimalne koštane mase postiže se tokom puberteta i adolescencije kroz takozvani "prozor mogućnosti" (Window of opportunity), a i do $90 \%$ do kraja druge dekade života (BarnekowBergkvist, 2005). Na postizanje maksimalne (peak) koštane mase mladih žena pozitivno utiču različiti oblici fizičke aktivnosti ali i nivo hormona rasta i IGF-I, kao i očuvan fiziološki menstrualni ciklus (Jurimae i Jurimae, 2008).

Mala energetska dostupnost (low energy availability) sa ili bez poremećaja ishrane, amenoreja i osteoporoza, pojedinačno ili povezani kao Triada predstavljaju značajan zdravstveni rizik za kost žene. Deficit estrogena uzrokovan HPA narušava postizanje maksimalne koštane mase kod mladih žena i može da značajno umanji pozitivan efekat fizičke aktivnosti na kost (Ducher i Eser, 2009). Posljedičnoj tome nastaje i osteoporoza, jedno od najtežih oboljenja kosti, a mineralni sastav kosti može biti toliko smanjen da se stress frakture javljaju i nakon minimalnog opterećenja kosti (Barrack i saradnici, 2013).

Dodatni deficit kalcijuma i proteina usljed poremećaja ishrane, te odgođena menarha još više pogoduju prevremenoj osteoporozi kod sportiskinja.

U skladu sa najnovijim preporukama primarni tretman Trijade započinje borbom protiv poremećaja ishrane. Kao najbolje riješenje su se pokazali povećanje energetskog unosa i smanjenje obima treninga da bi se energetski nivo povećao u mjeri koja će omogućiti ponovno usposltavljanje polne osovine žene. Takose 
riješava i treći simptom, zaustavljanjem gubljenje mineralne koštane gustine, pa tako i nastanka osteoporoze (Ibid).

\section{ZAKLJUČAK}

U odgovoru na jedno od navedenih pitanja sa početka teksta možemo da zaključimo sljedeće. Većina navedenih medicinskih stanja koja češće pogađaju fizički aktivne žene i sportiskinje su visoka cijena za bavljenje sportom, suštinski zdravom aktivnošću. Isto tako, namjera nam je bila da prikažemo tu nježnu granicu gdje završava sport a počinje medicina. $\mathrm{Na}$ sreću, većina opisanih poremećaja su rezultat grešaka tokom trenažnog procesa i mogu spriječiti preventivnim mjerama. Davno je rečeno da je „bolje spriječiti nego liječiti“. Upoznavanje sportiskinja, trenera, roditelja i ljekara sa ovom problematikom predstavlja ujedno i prvi korak.

\section{LITERATURA}

Barnekow-Bergkvist, M., Hadberg, G., Pettersson, U., \& Lorentzon, R. (2005). Relationships between physical activity and physical capacity in adolescent females and bone mass in adulthood. Scand J Med Sci Sports, 14, 1-9.

Barrack, M. T., Ackerman, K. E., \& Gibbs J. C. (2013). Update on the female athlete triad. Curr Rev Musculoskelet Med, 6(2), 195-204. doi: 10.1007/s12178-013-9168-9; PMid: 23613226

Bjorntorp, P. (1986). Fat cells and obesity. In K. D. Bronwell (Ed.), Handbook of eating disorders (pp. 88-98). New York, NY: Basic Books.

Catherine, M., Gordon, M. D. (2010). Functional Hypothalamic Amenorrhea. $N$ Engl J Med, 363, 365-371.

Coelho, G. M., de Farias, M. L., de Mendonça, L. M., de Mello, D. B., Lanzillotti, H. S., Ribeiro, B. G., Soares Ede, A. (2013). The prevalence of disordered eating and possible health consequences in adolescent female tennis players from Rio de Janeiro, Brazil. Appetite, 64, 39-47. doi: 10.1016/j.appet.2013.01.001; PMid: 23318655

Deimel, J. F., \& Dunlap, B. J. (2012). The female athlete triad. Clin Sports Med, 31(2), 247-254. doi: 10.1016/j.csm.2011.09.007; PMid: 22341014

Diagnostic and statistical manual of mental disorders, DSM-IV (1994). In: Diagnostic and statisticl manual of mental disorders, DSM-IV. American Psychiatric Association (1st ed) Washington D.C.
Drinkwater, B., Loucks, A., Sherman, R. T., Sundgot-Borgen, J., Thompson, R. A. (2005). IOC Medical Comissission Working Group: Position Stand on The Female Athlete Triad. Retrived from httc://www.olympic.ogr.

Ducher, G., Eser, P., Hill, B,. \& Bass, S. (2009). History of amenorrhea compromises some of the exercise-induced benefits in cortical and trabecular bone in the peripheral and axial skeleton: a study in retired elite gymnasts. Bone, 45, 760-767. doi: 10.1016/j.bone.2009.06.021; PMid: 19573632

Elford, K. J., \& Spence, J. H. (2002). The forgotten female: Pediatric and adolescent gynecological concerns and their reproductive consequences. $J$ Pediatr Adolesc Gynecol, 15, 65-77. doi: 10.1016/ S1083-3188(01)00146-2

Goldstein, M. A., Dechant, E. J., \& Beresin, E. V. (2011). Eating disorders. Pediatr Rev., 32(12), 508-521. doi: 10.1542/pir.32-12-508; PMid: 22135421

Greydanaus, D., \& Patel, D. (2002). The female athlete before and beyond puberty. Pediatr Clin N Am., 49, 553-580. doi: 10.1016/S00313955(02)00005-6

Hagen T. (2005). Sports medicine and the adolescent female. J Pediatr Adolesc Gynecol, 18, 9-15. doi: 10.1016/j.jpag.2004.11.005; PMid: 15749579

Ireland, M., \& Ott, S. (2004). Special conserns of the female athlete. Clin Sports Med, 23, 281-289. doi: 10.1016/j.csm.2004.04.003; PMid: 15183572

Jurimae, J., \& Jurimae, T. (2008). Bone Metabolism In Young Female. Kinesiology, 1, 39-49.

Kenney, L. W., Wilmore, H. J., \& Costil, L. D. (2012). Physical Activity for Health and Fitness. In: Physiology of sport and exercise. 5th ed. Champaign. IL: Human Kinetics.

Mitchell, N., \& Ennis, L. A. (2007). Encyclopedia of Title IX and Sports. Westport: Greenwood Press.

Myer, G., \& Ford, K. (2004). Methodological approach and rationale for training to prevent anterior cruciate ligament injuries in female athlete. Scand J Sci Sports, 14, 275-285. doi: 10.1111/j.1600-0838.2004.00410.x; PMid: 15387801

Nativ, A., Loucks, A., Manore, M., Sanborn, C., Sundgot-Borgen, J., \& Warren, M. (2007). ACSM Position Stand; The Female Athlete Triad. Med Sci Sports Exerc, 39, 1867-1882. doi: 10.1249/mss.0b013e318149f111; PMid: 17909417 
Otis, C. L., Drinkwater, B., Johnson, M., Loucks, A., \& Wilmore, J. (1997). American College of Sports Medicine: Position stand; The female athlete triad. Med Sci Sports Exerc, 29, 5-16. doi: http:/ /dx.doi.org/10.1097/00005768199705000-00037

Pfister, G. (2000). Women and the Olympic Games. In B. L. Drinkwater (Ed.), Women in sport. Oxford, GB: Blackwell Science Ltd. doi: 10.1002/9780470757093.ch1

Ponorac, N. (2008). Sport kao rizik za nastanak poremé́aja ishrane, menstrualnog ciklusa i metabolizma kosti [Sport as a risk of eating disorders, menstrual cycle and bone metabolism]. Unpublished doctoral dissertation, University of Banja Luka, Medical Faculty.

Ponorac, N., Rašeta, N., Radovanović, D., Matavulj, A., Popadić-Gaćeša, J. (2011). Bone metabolism markers in sportswomen with menstrual cycle dysfunctions. J Med Biochem, 30(2), 1-5.

Sabatini, S. (2001). The female athlete triad. Am J Med Sci, 322, 193-195. doi: 10.1097/00000441200110000-00007; PMid: 11678514

Sundgot-Borgen, J., \& Larsen, J. (1993). Pathogenic weight-control methods and self-reported eatig disorders in female elite athletes and controls.
Scand J Med Sci Sports, 3, 150-155. doi: 10.1111/ j.1600-0838.1993.tb00379.x

Sundgot-Borgen, J., \& Torstveit, M. (2004). Prevalence of eatin disorders in elite athletes is higher than in the general population. Clin J Sport Med, 14, 25-32. doi: 10.1097/00042752200401000-00005; PMid: 14712163

Thein-Nissenbaum, J. (2013). Long term consequences of the female athlete triad. Maturitas, 75(2), 107-112. doi: 10.1016/j. maturitas.2013.02.010; PMid: 23541905

Thomson, R., \& Sherman, T. (1999). Good Athlete traits and characteristice of anorexia nervosa: Are they similar? Eating Disorders, 7, 181-190. doi: 10.1080/10640269908249284

U.S. Department of Health and Human Services. (1996). Physical activity and health: A report of the Surgeon General. Atlanta, GA: U.S. Department of Health and Human Services, Centers for Disease Control and Prevention, National Center for Chronic Disease Prevention and Health Promotion.

Yeager, K., Agostini, A., Nattiv, A., \& Drinkwater, B. (1993). The female athlete triad: disordered eating, amenorrhea, osteoporosis. Med Sci Sports Exerc, 25, 775-777. doi: 10.1249/00005768199307000-00003; PMid:8350697

Primljeno: 23. maj 2013. godine Izmjene primljene: 19. jun 2013. godine Odobreno: 19. jun 2013. godine

\author{
Korespondencija: \\ Dr Nenad Ponoraci \\ Medicinski fakultet \\ Save Mrkalja 14 \\ 78000 Banja Luka \\ Bosna i Hercegovina
} Telefon: 0038765515264 E-mail: ponirac051@yahoo.com 